\title{
Interactive comment on "Southern hemisphere bog persists as a strong carbon sink during droughts” by Jordan P. Goodrich et al.
}

\section{Anonymous Referee \#2}

\section{Received and published: 30 May 2017}

The manuscript presented by Goodich et al. is an important study on the carbon budget of a Southern hemisphere peatland ecosystem. The authors quantified fluxes of $\mathrm{CO} 2$, $\mathrm{CH} 4$ and DOC over a period of four consecutive years, which makes it a valuable dataset to study effect of climate conditions on the peatland's carbon dynamics. In particular, the authors discuss changes in carbon fluxes during a strong drought year. By estimating global warming potential of the study area, they authors underline the bog's importance as a net carbon sink.

In the presented study, adequate methods are used to address the peatland's carbon dynamic. Eddy covariance fluxes of $\mathrm{CO} 2$ and $\mathrm{CH} 4$ were measured with state-of-the art instrumentation and the authors performed a detailed quality control assessment. In addition, the manuscript is well structured and written. Scientific points are presented in a conclusive manner and the paper is nice to read.

Printer-friendly version

Discussion paper 
As the authors underline, there are little studies yet on the carbon dynamics of Southern hemisphere peatlands, which makes this study an important contribution. I suggest the manuscript to be published in Biogeosciences after addressing the two following issues:

1. As the authors state, the ecosystem respiration (ER) is positively correlated with the water table depth (WTD), although there might be a limit to the increase of ER with WTD. While the correlation between ER and WTD is not strong ( $R 2=0.2)$, it would be interesting to know what model function was used and if the authors considered using a different model? CO2 transport through the peat column is not necessarily linear, deeper layers are probably more compacted, contributing less to the carbon exchange. The below surface $\mathrm{CO} 2$ exchange is also governed by the vertical $\mathrm{CO} 2$ profile in the column. This might suggest that ER does not increase linearly with increased gas volume (pore space).

2. A major focus of the manuscript is the discussion of GPP and ER for the different years. The authors mention a possible over-estimation of GPP and ER with the applied ANN method. As it is an essential part of the manuscript, can the authors give an estimate of this over-estimation or give an approximate error of the flux partitioning in relation to the measured $\mathrm{CO} 2$ flux?

\section{Other comments:}

P. 3, L. 30: What was the height of the flux measurements (4.5 $\mathrm{m}$ or lower)? Do you have estimates of the corresponding footprint extent?

P. 4, L. 11: Göckede et al. (2006) use the scheme of Foken and Wichura (1996) in the revised version presented by Foken et al. (2004) for the flux quality assessment. As this scheme uses flags 1-9, which are the flags $1-5$ you are referring to?

P. 4, L. 12: Here it would be interesting to state what the magnitude of the retrieved storage flux correction is. 
P. 8, L. 3: PPDFD/VPD can be also interpreted as ratio. I suggest to provide an alternative here.

\section{References:}

Foken, T. and Wichura, B.: Tools for quality assessment of surface-based flux measurements, Agric. For. Meteorol., 78(1-2), 83-105, doi:10.1016/0168-1923(95)02248$1,1996$.

Foken, T., Göockede, M., Mauder, M., Mahrt, L., Amiro, B. and Munger, W.: Post-Field Data Quality Control, in Handbook of Micrometeorology, vol. 29, edited by X. Lee, W. Massman, and B. Law, pp. 181-208, Springer Netherlands., 2004.

Göckede, M., Markkanen, T., Hasager, C. B. and Foken, T.: Update of a footprintbased approach for the characterisation of complex measurement sites, BoundaryLayer Meteorol., 118(3), 635-655, doi:DOI 10.1007/s10546-005-6435-3, 2006.

Interactive comment on Biogeosciences Discuss., doi:10.5194/bg-2017-97, 2017. 